\title{
AVIAN SPECIATION IN THE PANTEPUI: THE CASE OF THE RORAIMAN ANTBIRD (PERCNOSTOLA [SCHISTOCICHLA] "LEUCOSTIGMA" SATURATA)
}

\author{
Michael J. Braun ${ }^{1,5}$, Morton L. Isler ${ }^{2}$, Phyllis R. Isler ${ }^{2}$, John M. Bates 3 , \\ AND MARK B. RoBbins ${ }^{4}$ \\ ${ }^{1}$ Department of Vertebrate Zoology, National Museum of Natural History, Smithsonian Institution, \\ 4210 Silver Hill Rd., Suitland, MD 20746 \\ ${ }^{2}$ Department of Vertebrate Zoology-Birds, National Museum of Natural History, Washington, DC. 20560-0116 \\ ${ }^{3}$ Department of Zoology, Field Museum of Natural History, 1400 S. Lake Shore Dr., Chicago, IL 60605-2496 \\ ${ }^{4}$ Division of Birds, University of Kansas Natural History Museum, Lawrence, KS 66045
}

Abstract. We document the first records for Guyana of Roraiman Antbird (Percnostola [Schistocichla] "leucostigma" saturata), an endemic of the tepui highlands of southeastern Venezuela, northern Brazil and western Guyana. This form is well differentiated from nominate leucostigma (Spot-winged Antbird) of the Guianan lowlands in morphology, vocalizations, and genetics, and replaces it both altitudinally and ecologically. The two taxa are distributed parapatrically on the continuously forested northeastern slopes of the eastern tepuis, and they almost certainly come into contact, yet there is no evidence of intermediacy. We recommend that saturata be treated as a distinct species of Percnostola, and consider its' origin in the light of various models of speciation in the tepuis.

Key words: biodiversity, Neotropics, Percnostola, speciation, systematics, tepuis, Thamnophilidae.

\section{Especiación de Aves en el Pantepui: El Caso de Percnostola (Schistocichla) "leucostigma" saturata}

Resumen. En este trabajo documentamos los primeros registros para Guyana de Percnostola (Schistocichla) "leucostigma" saturata, un hormiguero endémico de las montañas del sureste de Venezuela, norte de Brazil y oeste de Guyana. Esta forma se diferencia notablemente en morfología, vocalizaciones y genética de $P$. l. leucostigma, presente en las tierras bajas de las Guyanas, y la reemplaza altitudinal y ecológicamente. Los dos taxa tienen distribuciones parapátricas en los bosques continuos de las laderas noreste de los tepuis del este, y casi con seguridad están en contacto, aunque no hay señales de hibridización. Recomendamos que saturata sea tratada como una especie distinta de Percnostola, y discutimos su origen considerando varios modelos de especiación en los tepuis.

\section{INTRODUCTION}

The Neotropical region has the highest level of biological diversity for birds and many other groups of organisms. The processes that generate this remarkable richness are of broad theoretical and practical interest. While numerous diversity-generating mechanisms have been proposed (Wallace 1852, Mayr and Phelps 1967, Haffer 1969, Endler 1977, Tuomisto et al. 1995), the efficacy and relative importance of these mechanisms is an area of active research and debate (Endler 1982, Capparella 1991, Bush

Manuscript received 20 June 2004; accepted 23 January 2005.

${ }^{5}$ E-mail: braun@lab.si.edu
1994, Brumfield and Capparella 1996, Haffer 1997).

The Pantepui region of southern Venezuela, northern Brazil, and western Guyana has long been recognized as an area of special interest in the study of Neotropical biodiversity. The region is characterized by tall sandstone mesas (tepuis), that rise steeply from savanna or forest-covered plains to heights of $1500-3000 \mathrm{~m}$. Formed by millions of years of erosion of an ancient uplifted plateau on the Guianan Shield, the tepuis are surrounded by steep talus slopes that are generally covered with dense subtropical or temperate vegetation. The slopes and summits of the tepuis support a distinctive highland biota remarkable for its high degree of endemism. While endemic plants, reptiles, and amphibians are often differentiated at the generic or subge- 
neric level (Steyermark 1986, McDiarmid and Donnelly 2005), endemic birds have been accorded species or subspecies rank, suggesting that they are relatively young taxa (Mayr and Phelps 1967). Avian speciation is likely to be ongoing in the region, making the tepui avifauna an attractive model system for the study of mechanisms that generate biodiversity.

Several classic analyses of the tepui avifauna have been published (Chapman 1931, Mayr and Phelps 1967, Cook 1974). These analyses have contributed a great deal to our understanding of diversification, both in the tepuis and in the Neotropics. However, many tepuis are relatively inaccessible, and have been little studied. Ongoing fieldwork indicates that there is much still to be learned about the community composition and basic ecology of tepui birds (Willard et al. 1991, Barrowclough et al. 1995, 1997, Perez-Eman et al. 2003, Braun et al. 2003). New methods, such as genetics and the analysis of vocalizations, are likely to yield useful insights into their origin and degree of differentiation as well.

One example is the case of Percnostola (Schistocichla) "leucostigma" saturata, an antbird previously known only from the understory of highland forests on the tepuis in the Gran Sabana region of southeastern Bolívar, Venezuela and adjacent Roraima, Brazil (Fig. 1). Though relegated to subspecies status for the past 70 years, recent fieldwork demonstrates that saturata occurs in close proximity to nominate leucostigma, yet is vocally and ecologically distinct. Comparative analyses of morphology, vocalizations, and mitochondrial DNA sequence variation show that saturata and leucostigma are differentiated in many ways with no evidence of intermediacy at the range interface. Here we report those results, resurrect saturata as a species, and consider plausible modes of origin.

\section{TAXONOMIC BACKGROUND}

Originally described as a species by Salvin (1885) on the basis of one male and one female collected by $\mathrm{H}$. Whitely at Mt. Roraima, saturata was treated as conspecific with leucostigma by Cory and Hellmayr (1924), who made both subspecies of Sclateria schistacea (Slate-colored Antbird). Todd (1927) listed saturata as a species in his newly erected genus Schistocichla, but he noted "No specimen of this form has been examined." Because of sympatry, Zimmer (1931) treated leucostigma and schistacea as

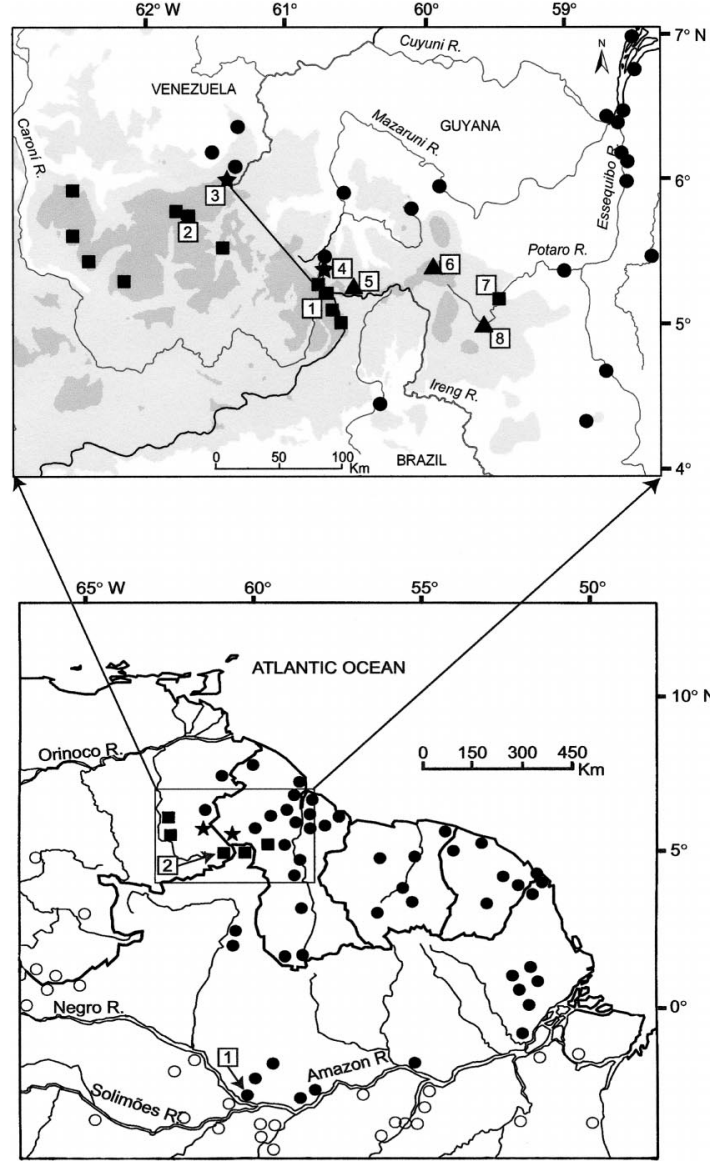

FIGURE 1. Geographic ranges of Percnostola l. leucostigma and $P$. saturata. Solid circles $=$ locations of $P$. l. leucostigma. Unfilled circles = locations for other subspecies of $P$. leucostigma. Squares $=$ locations of $P$. saturata, including $P$. $s$. obscura . Stars $=$ locations where $P$. l. leucostigma and $P$. saturata are found in elevational parapatry. Triangles $=$ taxon or exact location unclear. Lower panel: Symbols in this panel represent the occurrence of taxa within small sectors (Isler 1997). 1. Type locality of $P$. l. leucostigma = Manaus, Amazonas, Brazil. 2. Type locality of P. s. saturata $=$ Mt. Roraima, Bolívar, Venezuela. Rectangle delimits area of upper panel. Upper panel: Known locations of $P$. saturata and surrounding locations for $P$. l. leucostigma . Light shading $=$ areas above $500 \mathrm{~m}$ in elevation. Dark shading $=$ areas above $1000 \mathrm{~m}$ in elevation. 1. Type locality of P. s. saturata $=$ Mt. Roraima. 2 . Type locality of $P$. s. obscura $=$ Sororopán-tepuí. 3 . La Escalera and Sierra de Lema. 4. North slope Mt. Roraima, between 500-m and 800-m camps. 5. Adaroo River, elevation and exact location uncertain. 6. Ayanganna Mountain, elevation and taxon uncertain. 7. Kaieteur Fall. 8. Chenapou, $600 \mathrm{~m}$, taxon unidentified. Coordinates and place names of older localities in the Guianas follow Stephens and Traylor (1985). 
species, but he did not discuss saturata, and listed it as a subspecies of leucostigma. In the same year, Chapman (1931) also treated saturata as a subspecies of leucostigma without comment, and it has languished in obscurity ever since (Peters 1951, Mayr and Phelps 1967, Meyer de Schauensee and Phelps 1978, Willard et al 1991, Ridgely and Tudor 1994, but see Hilty 2003, Zimmer and Isler 2003). As currently conceived, $P$. leucostigma is a widespread, polytypic species with nine mostly well-marked subspecies ranging throughout lowland Amazonia and into the subtropical zone in the Pantepui and the foothills of the Peruvian and Bolivian Andes. Here, we show that saturata deserves species status, and we refer to it as P. saturata throughout.

Zimmer and Phelps (1946) described a second tepui subspecies, obscura, from Sororopán-tepuí, Auyán-tepuí, and Ptari-tepuí, mountains in the northern Gran Sabana, about 140 km northwest of Mt. Roraima. However, the differences between saturata and obscura are slight at best (see below), and saturata has priority, so we routinely use it here to refer to all tepui highland birds of this complex, and use obscura only when we consider it separately from saturata.

The generic placement of these taxa also requires comment. Early authors placed them variously in the genera Percnostola (von Pelzeln 1868), Heterocnemis (Salvin 1885), and Sclateria (Chubb 1921, Cory and Hellmayr 1924). Todd (1927) did not explicitly consider Percnostola when he described Schistocichla, despite the fact that von Pelzeln (1868) had described leucostigma as a Percnostola. Without comment to generic allocation, Zimmer (1931) also placed schistacea and leucostigma (including saturata) within Schistocichla. Peters (1951) subsumed Schistocichla into Percnostola without discussion, and his expanded genus Percnostola was maintained by most authors for more than 40 years. Ridgely and Tudor (1994) resurrected the genus Schistocichla, which they distinguished from other Percnostola species as having "rounder and uncrested heads and in having spots, not fringing, on their wing coverts." However, some taxa (minor, jensoni, arenarum) in the Black-headed Antbird (Percnostola rufifrons) group are essentially uncrested (Isler et al. 2001) and other thamnophiline genera (e.g., Thamnophilus) include both species with spots and species with fringing on wing coverts. Thus, there is as yet no firm basis for splitting Schistocichla from Percnostola and we prefer to maintain the single genus Percnostola until a thorough analysis is published.

\section{METHODS}

\section{STUDY SITES}

Along with colleagues, we (MJB and MBR) surveyed the avifauna along an elevational transect of the north slope of Mt. Roraima on expeditions in 1994 and 2001. We encountered Percnostola at four camps on this transect.

475-m Camp. We surveyed the avifauna at this site $\left(5^{\circ} 29^{\prime} \mathrm{N}, 60^{\circ} 47^{\prime} \mathrm{W}\right)$ from 31 October to 15 November 1994, and again 10-11 March and 16-17 April 2001. It lies on level terrain in undisturbed, seasonally flooded forest on the right bank of the Waruma River. See Results for further description of the habitat.

500-m Camp. We visited this site $\left(5^{\circ} 23^{\prime} \mathrm{N}\right.$, $60^{\circ} 46^{\prime} \mathrm{W}$ ) on $12-14$ March and 15 April 2001. It is also in level terrain on the right bank of the Waruma River, about $9.7 \mathrm{~km}$ upstream from the 475-m Camp. The habitat was similar to that found at $475 \mathrm{~m}$.

800-m Camp. We surveyed birds at this site $\left(5^{\circ} 17^{\prime} \mathrm{N}, 60^{\circ} 45^{\prime} \mathrm{W}\right)$ from $18-27$ March 2001. The camp was on the lower slopes of Mt. Roraima, in tall, humid, closed-canopy forest transitional between the lowland and montane forests of the area.

1300-m Camp. We studied the avifauna here $\left(5^{\circ} 16^{\prime} \mathrm{N}, 60^{\circ} 44^{\prime} \mathrm{W}\right)$ from 28 March to 12 April 2001. This camp was in epiphyte-laden cloud forest of lower stature (up to $20 \mathrm{~m}$ ) and more open canopy than the forest at $800 \mathrm{~m}$ or below.

We surveyed the avifauna at each camp, recording data on habitat and behavior, taping vocalizations, and collecting specimens with mist nets and shotguns. More information on the 2001 fieldwork can be found in Braun et al. (2003). Specimens are deposited at the US National Museum of Natural History (USNM), University of Kansas Natural History Museum (KUNHM), and the University of Guyana. Tape recordings are deposited at the Macaulay Library of Natural Sounds of the Cornell Laboratory of Ornithology. All work was conducted under research permits issued by the Environmental Protection Agency of Guyana.

\section{MORPHOLOGY}

Only adult specimens in definitive plumage were used for morphological comparisons. Plumage 
color differences were assessed by visual comparison of our recently collected material and specimens from five major collections (Appendix A). Together, these collections hold the majority of all specimens of saturata and obscura known to us. Soft-part colors were recorded from specimen tags as described by the original collectors. Exposed culmen and tail length (from insertion of central rectrices to tip) were measured with dial calipers to the nearest $0.1 \mathrm{~mm}$. Wing chord was measured with a millimeter scale ruler to the nearest $0.5 \mathrm{~mm}$ as the distance from the anterior edge of the wrist joint to the tip of the longest primary on the unflattened, closed left wing.

\section{VOCALIZATIONS}

Tape recordings of adult male (as identified by recordists and implied by analysis) nominate leucostigma, saturata, and obscura were compiled from our own inventories, contributions from other individuals, and public archives. Appendix $\mathrm{B}$ provides a detailed list of recordings used in this study (71 recordings from 18 localities). Canary 1.2 (Charif et al. 1995) was used to make a spectrogram of every vocalization type delivered by each individual of either sex on every recording. Spectrograms were visually compared to sort vocalizations by type and to determine whether there were any obvious variations within vocal types.

Spectrograms were examined to consider whether they were of sufficiently high quality to allow quantitative measurements. Quantitative measures of vocal characters were made of all suitable recordings of saturata and obscura but were restricted to a sample of recordings of nominate leucostigma. Whenever possible, we measured three examples of each vocalization for each individual. Spectrograms were projected on the screen of a Macintosh G4 computer using default settings of Canary 1.2 except that the display was set to smooth, overlap was adjusted from $50 \%$ to $94 \%$ depending on recording quality, and contrast was adjusted according to recording intensity with care taken to retain all elements of the vocalization. Cursor measurements were made typically at scales of $0.3 \mathrm{sec}$ inch $^{-1}$ and $4.0 \mathrm{kHz}$ inch $^{-1}$. We obtained 55 measures of twelve vocal characters that included the number of notes, duration, pace (notes per second), change in pace, note shape, change in note shape, note length, change in note length, interval length (time between notes), change in interval length, note peak frequencies, and change of note peak frequencies. Visual and mensural characters were selected to distinguish populations of each pair only if they were considered independent. This required careful judgment of whether variation in one character could occur without resulting in a different outcome for another character.

\section{GENETICS}

Tissues for DNA sequencing were collected and frozen in the field under standard protocols. DNA sequences were generated in the Pritzker Laboratory for Molecular Evolution and Systematics of The Field Museum. DNA amplification and sequencing was conducted using standard protocols (Bates et el. 1999). Sequence data were generated for the mitochondrial genes ATPase 6 (678 bp), ND2 (1041 bp), and ND3 (345bp). The primers pairs used to amplify the different genes were as follows: ND3 (H11151: 5'GATTTGTTGAGCCGAAATCAAC, L10755: 5'GACTTCCAATCTTTAAAATCTGG); ATPase 6 (CO3HMH: 5'CATGGGCTGGGGTCRACTATG TG, A8PWL: 5'-CCTGAACCTGACCATGAA C); ND2 (L-met: 5'-TATCGGGCCCATACCCC GAAAAT, 5'-ND2THL: TCARCAGCCCTGGG CGGCTGAGC, 5'-ND2THH: GAGAGATGGAG GAAAAGGCTAGG, TrpC: 5'-CCTTTATTTAA GGCTTTGAAGGC). Sequences of saturata and leucostigma have been deposited in GenBank (Accession Nos. AY921070-AY921162).

\section{STATISTICAL ANALYSES}

Significance of morphometric differences was assessed with two-tailed $t$-tests assuming equal variances (Microsoft Excel). We report genetic divergence as the level of uncorrected percent sequence divergence $(p)$ calculated with PAUP* (Swofford 2002). In defining vocal characters that relate to species differences in antbirds, we are interested in identifying distinct character states that have the potential for unambiguous signal recognition. Thus, rather than use standard statistical tests which would only test for difference of means, we apply more stringent criteria which require diagnostic differences in vocal characters to represent discrete, nonoverlapping character states as described in detail in earlier papers (Isler et al. 1998, 1999). In the case of continuous variables, ranges could not overlap and the means $(x)$ and standard devia- 
tions (SD) of the population with the smaller set of measurements $(a)$ and the population with the larger set of measurements $(b)$ had to meet the requirement:

$$
x_{\mathrm{a}}+t_{\mathrm{a}} \mathrm{SD}_{\mathrm{a}} \leq x_{\mathrm{b}}-t_{\mathrm{b}} \mathrm{SD}_{\mathrm{b}},
$$

where $t_{\mathrm{i}}=$ the $t$-score at the 97.5 percentile of the $t$ distribution for $n-1$ degrees of freedom (except for ratios where this statistical test is inappropriate).

\section{RESULTS}

\section{DISTRIBUTION, ECOLOGY, AREAS OF PARAPATRY}

The first evidence that saturata occurs in Guyana came when MJB and C. M. Milensky tape recorded a pair of Percnostola on the Potaro Plateau at Kaieteur Fall $\left(5^{\circ} 11^{\prime} \mathrm{N}, 59^{\circ} 29^{\prime} \mathrm{W}\right)$ on 25 September 1998 (Fig. 1). We (MLI and PRI) recognized these vocalizations as saturata, previously known only from the eastern tepui highlands of the Gran Sabana region of Venezuela, about $140 \mathrm{~km}$ to the west. The low elevation $(400 \mathrm{~m})$ of the Potaro Plateau and its juxtaposition with humid Guianan lowland forests where nominate leucostigma is widespread, led us to suppose that saturata and leucostigma may come into contact in this area. In April 2002, MBR found saturata on a trail below Kaieteur Fall at an elevation of $125 \mathrm{~m}$. Though this record comes from an elevation more typical of nominate leucostigma, the habitat at the site was still dominated by the primary forest on steep slopes and clear, fast-moving streams that characterize saturata habitat at higher elevations. No specimens have been taken in this area because Kaieteur Fall lies within Kaieteur National Park.

Finding saturata at Kaieteur Fall led us to pay particular attention to the distribution of Percnostola on an elevational transect of the north slope of Mt. Roraima in 2001 (Braun et al. 2003). The north and east slopes of Mt Roraima are covered in continuous forest from the Guianan lowlands up to more than $2000 \mathrm{~m}$, providing an opportunity for the two forms to come together (Fig. 1). We found nominate leucostigma at 475-m and 500-m camps on the Roraima transect, in undisturbed forest along the Waruma River. There is little topographical relief at these sites, and level terrain continues for several more kilometers along the trail toward the foot of Roraima. The forest is tall $(30-40 \mathrm{~m})$ with a closed canopy at both sites, but the ground is swampy and subject to periodic flooding. We found leucostigma to be uncommon at these sites, but lack of vocal activity in the months we were there may have made them hard to detect. Of the birds we did locate, most occurred in pairs in the forest undergrowth near the river itself or along quiet watercourses in the forest. The avifauna at these sites was dominated by taxa typical of the Guianan lowlands.

We found saturata down to $700 \mathrm{~m}$ on the Roraima transect. The species was fairly common at both our $800-\mathrm{m}$ and $1300-\mathrm{m}$ camps, occurring in pairs, often in dense streamside vegetation along the rushing mountain creeks. The terrain at these sites is steep and rocky. The forest at $800 \mathrm{~m}$ is still tall $(30-40 \mathrm{~m})$ with a closed canopy, but appears transitional toward highland forest, with more abundant epiphytes than at 475 $\mathrm{m}$ and $500 \mathrm{~m}$. Many highland birds were found at $800 \mathrm{~m}$. At $1300 \mathrm{~m}$, the vegetation is epiphyteladen cloud forest, and the avifauna is dominated by highland elements (Braun et al. 2003).

We did not encounter either leucostigma or saturata between 500 and $700 \mathrm{~m}$, a straight-line distance of $12.5 \mathrm{~km}$, although we had two overnight camps in the intervening region and spent several days on the trail. However, we did not set nets at either overnight camp, and the trail was often on ridgetops instead of stream valleys where Percnostola would be more common. Thus, it seems quite likely that saturata and leucostigma actually do come into contact in this area, as mountain streams merge to become slower rivers on the more level lowland terrain. Noticeable relief begins between 500 and 550 $\mathrm{m}$, and several highland bird taxa were observed at $550 \mathrm{~m}$, such as Herpsilochmus roraimae (Roraiman Antwren), Pyrrhura egregia (Fieryshouldered Parakeet) and Myiophobus roraimae (Roraiman Flycatcher).

A third area where the ranges of nominate leucostigma and saturata are known to abut is on the Sierra de Lema in southeastern Bolívar, Venezuela (Fig. 1). Specimens in the Colleción Ornitológica Phelps (COP; Caracas) and tape recordings of vocalizations (Appendix B) demonstrate that typical leucostigma occurs at elevations up to $700 \mathrm{~m}$ on the Sierra de Lema (one male and one female in COP from $\mathrm{km} 109$ on Hwy 10), while saturata occurs at elevations as low as $1000 \mathrm{~m}$ (eight males and three females in COP from km 125 on Hwy 10). As at Kaieteur Fall and the north slope of Roraima, con- 
tinuous forest connects highland and lowland habitats on the Sierra de Lema, so it appears likely that the two forms come into contact in this area.

Other records from near the range interface in Guyana are insufficiently detailed for present purposes (Fig. 1). A COP specimen of leucostigma taken on the Pinkus-Peberdy Expedition of 1938-1939 is labeled "Adaroo River", but the exact locality and elevation are uncertain (Peberdy 1941). A sight record of "leucostig$m a$ " from Chenapou, $600 \mathrm{~m}$ (Barnett et al. 2002) did not discriminate between leucostigma and saturata. Snyder (1966) gave Ayanganna Mountain, the easternmost tepui over $2000 \mathrm{~m}$ in elevation, as a locality for nominate leucostig$m a$, but the basis for her identification is unclear. The locality is almost certainly based on Roth (1960), who gave a brief report of the birds collected by S. Williams on the Thompson Ayanganna Expedition. In that report, no subspecific allocation was made for this taxon, which was called Sclateria leucostigma, although many other birds were determined to subspecies. The report contained both highland and lowland taxa, so either saturata, leucostigma, or both seem possible. The specimens were deposited at the British Guiana Museum (now Guyana Museum), so Snyder would have had a chance to review them in the 1960's during her work on the avifauna, but she did not mention doing so. Moreover, it seems possible that Snyder was not aware of the distinctiveness of saturata. She listed birds known from Mt. Roraima but not yet found in Guyana proper (Snyder 1966). The list includes many subspecies, but $P$. $l$. saturata is not on it. Unfortunately, the Ayanganna specimens may now be lost. Answers to recent inquiries by several scientists indicate that the Guyana Museum no longer maintains a research collection (MBR, M. Tamessar, R. Ridgely, pers. comm.).

\section{MORPHOLOGY}

We first examined the two highland forms obscura and saturata to see if they were consistently separable. Zimmer and Phelps (1946) distinguished obscura from saturata on the basis of generally darker plumage tones of both males and females, but had very few saturata specimens for comparison (one male and five females). Small series of obscura and saturata were directly compared by MJB at USNM, COP, and the American Museum of Natural History (AMNH). Male obscura do appear blacker than saturata, but only slightly so. Female obscura average slightly darker brown below than female saturata, but the differences in female crown and back color mentioned by Zimmer and Phelps were not evident, either in entire series or in age-matched samples. Neither could differences be found in body measurements or soft part colors. We therefore combined samples of saturata and obscura, and refer to them as saturata in the following comparison to nominate leucostigma.

The chief difference in plumage between $s a$ turata and leucostigma is that saturata is darker in color in both sexes, especially on the underparts. Chubb (1921) described the type specimens of saturata in some detail, noting that the saturata male is "blackish-slate" above and below, whereas the male of leucostigma is "paler on the throat, breast, abdomen, and underwing coverts..." The female of leucostigma is "chocolate-brown" above, and "bright ferruginous" below. The female of saturata is subtly darker above, more noticeably darker below with the "throat and breast chestnut". The plumage differences described by Chubb (1921) hold consistently for both sexes in all the material examined by us, including 68 saturata (38 male, 30 female) from Guyana, Venezuela, and Brazil and 30 nominate leucostigma (19 male, 11 female) from Venezuela, Guyana, Surinam, and Brazil (Appendix A).

The difference in male bill color mentioned by Salvin (1885) is also supported by recent material. Nine of ten male saturata for which the soft part colors were recorded during specimen preparation had all black bills, and the tenth (USNM 626860) had a black bill, with the base of the mandible gray. In contrast, seven of eight male nominate leucostigma had the maxilla black, but the mandible was gray or blue-gray, with variable amounts of black at the base or tip. This difference may also be seen in preserved specimens; all additional male leucostig$m a$ skins for which bill color was checked $(n=$ 7) had pale mandibles. In fact, in the case of the single male leucostigma for which the bill color was recorded as "black" in life (KUNHM 88188), the mandible of the preserved specimen is actually dark gray brown (MJB, pers. obs.), so the field notes may be in error. There is less difference in female bill color, with five of five 
TABLE 1. Comparison of morphological measurements (mean [range], $n$ ) between adult specimens of Percnostola l. leucostigma and $P$. saturata. $P$. saturata measurements include both saturata and obscura. All $P$ values are shown prior to multiple test correction. Using the correction procedure of Hochberg (1988), the adjusted critical value over all tests was $\alpha<0.0083$.

\begin{tabular}{|c|c|c|c|c|}
\hline & $\begin{array}{l}\text { Wing chord } \\
(\mathrm{mm})\end{array}$ & $\begin{array}{l}\text { Tail length } \\
(\mathrm{mm})\end{array}$ & $\begin{array}{l}\text { Exposed culmen } \\
(\mathrm{mm})\end{array}$ & Mass (g) \\
\hline \multicolumn{5}{|l|}{ Males } \\
\hline leucostigma & 68 (67-71), 15 & $55.4(51.0-58.5), 12$ & $19.3(18.1-20.0), 15$ & $25.5(22.0-28.5), 8$ \\
\hline saturata & $65(62-66), 11$ & $55.7(53.3-59.0), 10$ & $17.2(16.4-18.0), 11$ & $25.0(24.0-26.2), 7$ \\
\hline$t$ & 7.0 & -0.3 & 9.4 & 0.6 \\
\hline$P$ & $<0.001$ & 0.74 & $<0.001$ & 0.60 \\
\hline \multicolumn{5}{|l|}{ Females } \\
\hline leucostigma & $66(62-70), 13$ & $56.8(53.5-58.3), 9$ & $19.2(18.1-20.5), 12$ & 25.8 (22.6-28.0), 5 \\
\hline saturata & $64(63-66), 5$ & $55.5(52.2-60.1), 5$ & $17.1(16.5-17.8), 5$ & $27.7(25.3-31.7), 3$ \\
\hline$t$ & 1.4 & 1.0 & 6.4 & -1.0 \\
\hline$P$ & 0.17 & 0.36 & $<0.001$ & 0.35 \\
\hline
\end{tabular}
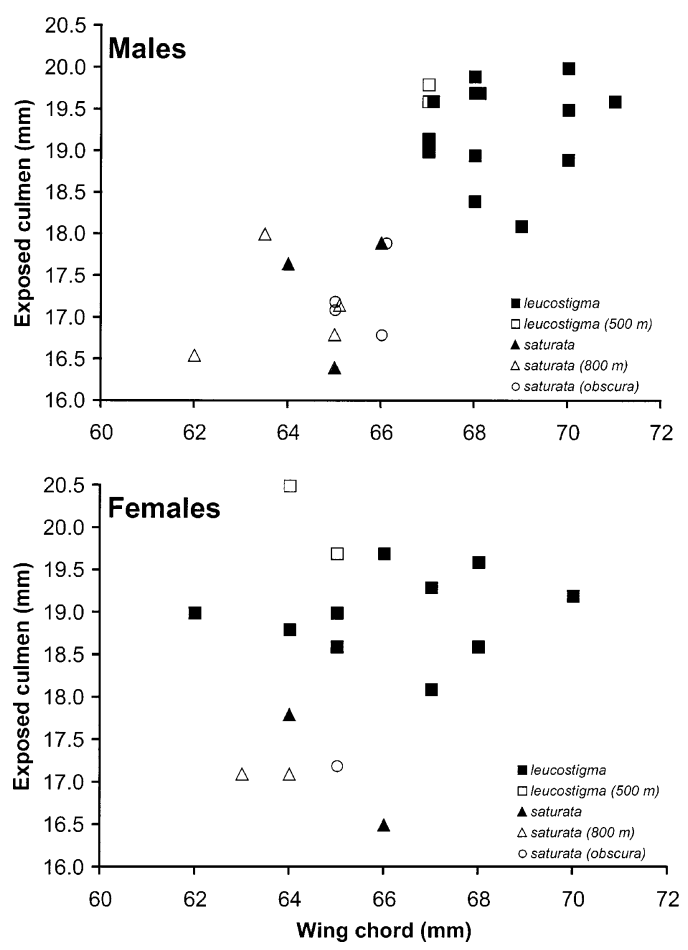

FIGURE 2. Plots of measurements of adult Percnostola specimens illustrate that male leucostigma $(n=$ $15)$ differ from male saturata $(n=11)$ in both exposed culmen length and wing chord, while female leucostigma $(n=12)$ differ from female saturata $(n=5)$ in exposed culmen length but not wing chord. Specimens from nearest the range interface on Mt. Roraima (500-m and 800-m camps) show no evidence of intermediacy. saturata and thirteen of thirteen leucostigma examined having at least a portion of the mandible paler than the maxilla.

As also noted by Salvin (1885), the legs and feet of saturata are often darker than those of nominate leucostigma, but this character appears somewhat variable. $P$. saturata tarsus colors were recorded ranging from "black" to "gray" $(n=10$ males, 4 females $)$, while the tarsus color of leucostigma was recorded as "blue gray" to "pinkish white" $(n=8$ males, 5 females). However, postmortem changes in softpart color may occur quickly, making fair comparison difficult.

An additional difference between the highland and lowland forms is the iris color, which consistently has been recorded as "gray" for nominate leucostigma ( $n=7$ males, 5 females), while that of saturata is usually recorded as "brown" or "gray brown" ( $n=7$ of 9 males, 3 of 3 females). However, the iris colors of two saturata males were recorded as "gray", so there may be some overlap in this character.

Besides the differences in plumage and soft part colors, nominate leucostigma had longer bill and wing measurements than saturata (Table 1, Fig. 2). The wing length difference was significant only for males, but the trend was the same for females, and it might well achieve statistical significance when larger sample sizes are available. There was a significant difference in exposed culmen length for both sexes (Table 1). There were no significant differences in tail length or mass, so the longer bill and wing of leucostigma are not simply due to body size alone. 

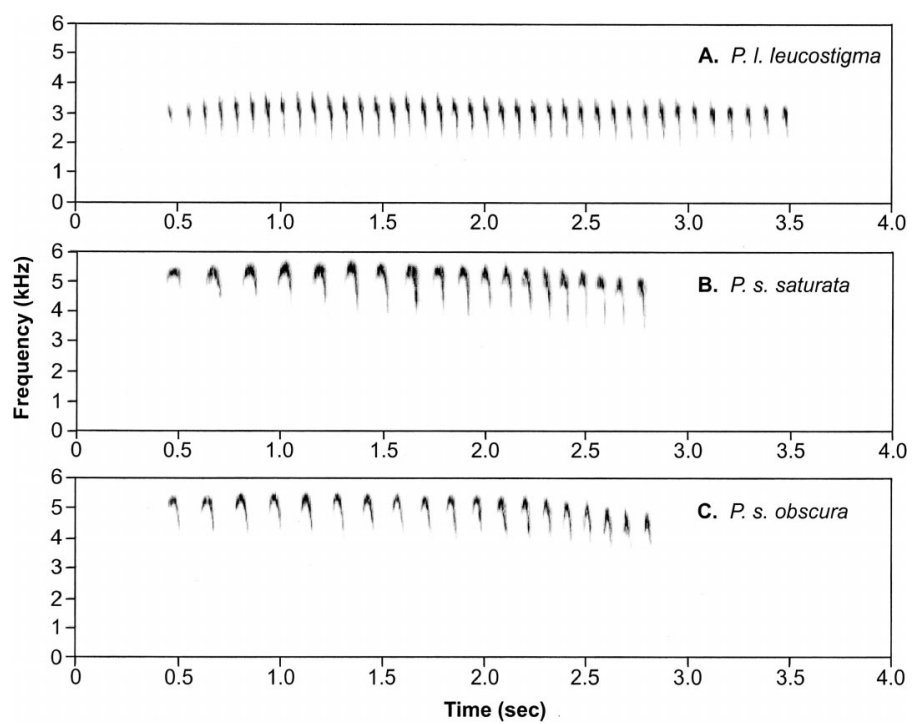

FIGURE 3. Loudsongs of A) Percnostola l. leucostigma, $80 \mathrm{~km}$ north of Manaus, Amazonas, Brazil, B) P. s. saturata, Waruma River, $15 \mathrm{~km}$ south of Kako River, Guyana, and C) P. s. obscura, La Escalera, $>1100 \mathrm{~m}$ in elevation, Bolívar, Venezuela. Spectrograms were chosen to represent typical values for vocal characters of each form.

The small series of specimens taken near the range interface on Mt. Roraima was examined for evidence of intermediacy. This series included four adult leucostigma skins and six adult saturata skins taken only 12.5 straight-line km apart. The plumage colors, soft part colors, and measurements of these specimens generally match those recorded for each species from allopatric localities, though it may be noted that the wing chord of the two leucostigma males falls at the lower end of the distribution of allopatric leucostigma (Fig. 2). One of these two, USNM 626837, is the darkest shade of gray, both above and below, of any nominate leucostigma with which it was directly compared (12 other adult males). However, it is only subtly darker than other leucostigma and does not approach the blackish-slate color of saturata.

\section{VOCALIZATIONS}

Eight recordings of nominate saturata were obtained at Kaieteur Fall and the north slope of Mt. Roraima. These were obtained at different recording sites and undoubtedly from different individuals. Seven recordings of obscura were made on the Sierra de Lema, near the upper limits $(>1100 \mathrm{~m})$ of the escarpment known as La Escalera $\left(05^{\circ} 58^{\prime} \mathrm{N}, 61^{\circ} 24^{\prime} \mathrm{W}\right.$; Fig. 1). We concluded that the obscura recordings were of dif- ferent individuals because the recordings were made by four different recordists over the period of a decade. Recordings of nominate leucostig$m a$ were taken at the base of La Escalera below the elevations at which obscura was found and in the lowlands of Bolívar, Venezuela, to the north ( $n=14$ recordings), northern Guyana ( $n$ $=18)$, southern Guyana $(n=8)$, Suriname $(n$ $=3$ ), and in the vicinity of Manaus, Amazonas, Brazil, the type locality $(n=10)$.

The taxa under study delivered four types of vocalizations termed loudsong, long call, short call, and rattle. No diagnostic differences could be distinguished between loudsongs (Fig. 3) of saturata and obscura, which were then combined as saturata for comparison to nominate leucostigma. Our conservative approach to defining diagnostic differences required that the ranges of values obtained for a vocal character did not overlap and, having met this criterion, the 95 percent confidence intervals around the means did not overlap. This criterion was met by representative measures of seven vocal characters that distinguished loudsongs of leucostig$m a$ and saturata (Fig. 3, Table 2). Diagnostic vocal characters included: (1) pace (leucostigma loudsongs were faster), (2) change of pace (leucostigma speeds up at beginning and slows down at end; saturata accelerates throughout 
TABLE 2. Diagnostic vocal characters and representative measurements distinguishing loudsongs of adult male leucostigma ( $n=11$ individuals) and saturata ( $n=9$ individuals). Recordings of saturata include six from Guyana and three from Venezuela (obscura). Sections 1, 2 and 3 reflect division of song into three equal time parts. Note 1 = first note; 2 = second note; $3=$ middle note; $4=$ next-to-last note; $5=$ last note. Intervals are spaces following the foregoing notes. Values are presented as mean \pm SD with range in parentheses.

\begin{tabular}{llcc}
\hline \hline \multicolumn{1}{c}{ Character } & \multicolumn{1}{c}{ Measurement } & \multicolumn{1}{c}{ leucostigma } & saturata \\
\hline Pace (notes per sec) & Overall pace & $12.66 \pm 0.98(11.28-14.73)$ & $7.31 \pm 0.82(6.33-8.62)$ \\
Change of pace & Ratio sections 1 to 3 & $1.01 \pm 0.06(0.93-1.11)$ & $0.62 \pm 0.07(0.51-0.74)$ \\
Note Length (msec) & Length note 2 & $29 \pm 5(19-36)$ & $69 \pm 12(57-85)$ \\
$\begin{array}{l}\text { Interval length (msec) } \\
\text { Change in interval }\end{array}$ & Length interval 2 & $59 \pm 9(43-69)$ & $115 \pm 14(98-140)$ \\
$\quad$ length & Ratio intervals 1 to 4 & $1.06 \pm 0.17(0.77-1.23)$ & $2.14 \pm 0.57(1.29-3.17)$ \\
$\begin{array}{c}\text { Frequency of note } \\
\text { peaks (kHz) }\end{array}$ & Peak frequency note 1 & $3.61 \pm 0.26(3.09-3.98)$ & $5.72 \pm 0.26(5.28-6.02)$ \\
$\begin{array}{c}\text { Change in peak fre- } \\
\quad \text { quencies }\end{array}$ & $\begin{array}{l}\text { Ratio peak frequencies } \\
\text { 2 to 5 }\end{array}$ & $1.04 \pm 0.04(0.95-1.07)$ & $1.10 \pm 0.04(1.08-1.25)$ \\
\end{tabular}

and at a faster rate than leucostigma at the beginning), (3) note length (initial leucostigma notes are shorter), (4) length of intervals between notes (leucostigma intervals are shorter throughout most of loudsong), (5) change in interval length (spacing between leucostigma notes was near even throughout; saturata intervals shorten), (6) frequency of note peaks (leucostigma lower pitched throughout), and (7) change in frequency of note peaks (leucostigma rises and falls gradually; saturata first half is flat or rises gradually but then falls somewhat sharply).

Only one possibly diagnosable difference was found between the calls and rattles of the three taxa (Fig. 4), but it could be the result of inadequate sample sizes for saturata and obscura, recordings of which were primarily of the loudsong. All three taxa delivered a downslurred and somewhat frequency modulated whistle, termed a long call (Fig. 4A-C). In the four available recordings of saturata and obscura, long calls were typically preceded by an abrupt, higherpitched note, which was absent in all sixteen recordings of leucostigma long calls. Also, long calls of saturata and obscura appeared more downslurred than those of leucostigma. The short call (Fig. 4D) was an abrupt unclear note given singly or in series of 2-5 notes, and the single recording of this call for saturata appeared indistinguishable from those of leucostigma. Finally, the rattle (Fig. 4E-G) was short, with a simpler note than the short call with which it was often intermixed; the single recordings of rattles for obscura and saturata were considered indistinguishable from those of leucostigma.

\section{GENETICS}

A total of $2064 \mathrm{bp}$ of mtDNA sequence data were collected for each of 10 saturata from Mt. Roraima and 20 nominate leucostigma from several widely separated localities in Guyana and near Manaus, Brazil (approximately 900 km apart). Within-taxon sequence divergence was less than $1 \%$ for each form. Levels of mtDNA sequence divergence between saturata and leucostigma samples averaged 9\% (range 8.8\%$9.1 \%, 200$ comparisons). The degree of differentiation is similar to that found with two samples of another Percnostola species, schistacea (Slate-colored Antbird), which had an average divergence of $10 \%$ from saturata (range 9.6\%$10.1 \%, 20$ comparisons) and $10 \%$ from leucostigma (range 9.9\%-10.0\%, 40 comparisons). Specimens from near the range interface (six saturata from 800-m camp and six leucostigma from 475-m and 500-m camps) all had mtDNA haplotypes consistent with their morphology.

\section{DISCUSSION}

\section{SPECIES STATUS}

From the analyses presented here, we conclude that saturata is diagnosably distinct from nominate leucostigma in numerous morphological, vocal, and genetic characters, and differentiated to a degree equal to, or greater than many congeneric thamnophilid species (Isler et al. 1998, Bates et al. 1999). The vocal and genetic differentiation of these forms is such that it is likely 


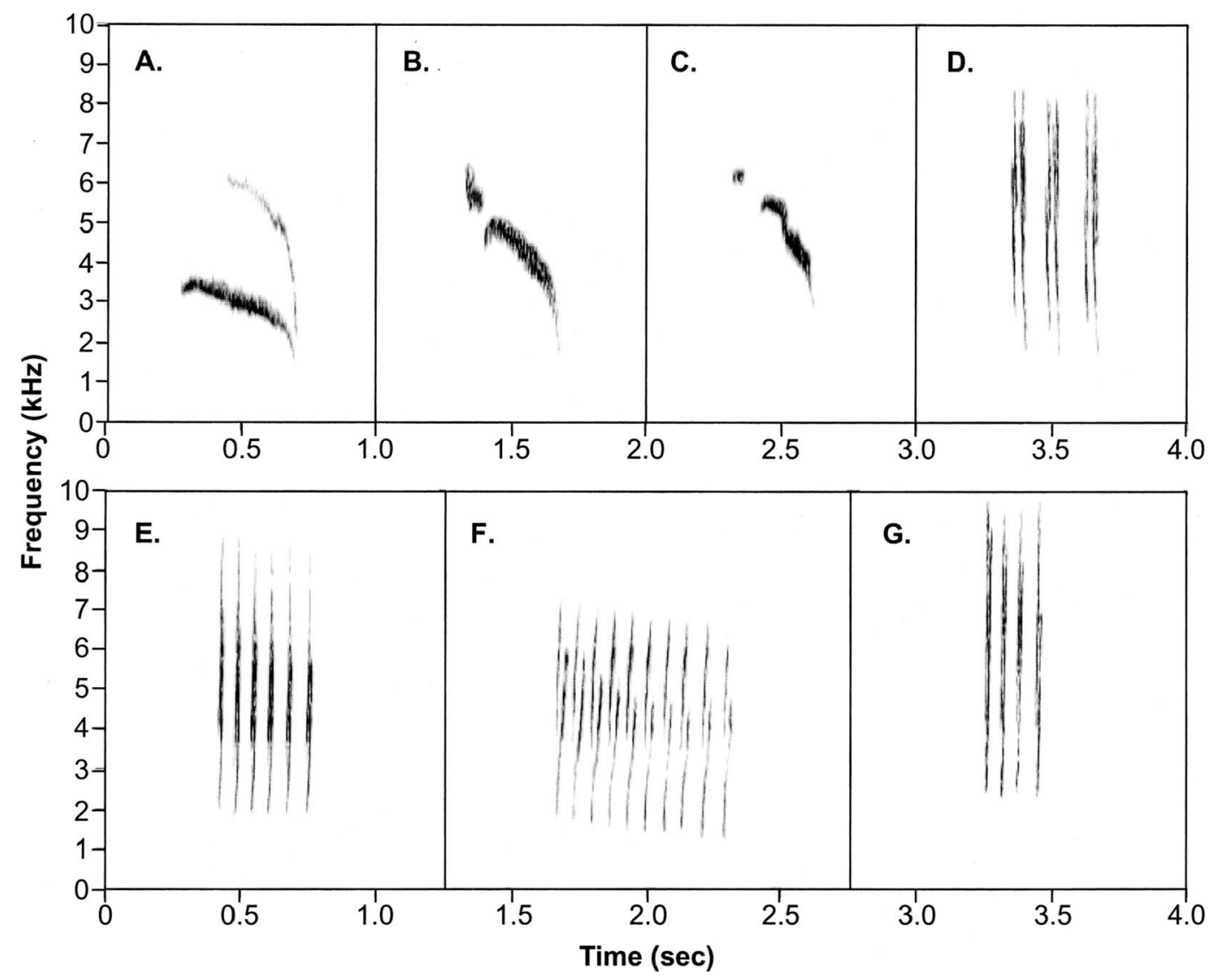

FIGURE 4. Long calls of A) Percnostola l. leucostigma, El Dorado-La Escalera Road, Bolívar, Venezuela, B) P. s. obscura, La Escalera, $>1100$ m, Bolívar, Venezuela, and C) P. s. saturata, Kaieteur Fall, Guyana. Examples of a short call of D) P. l. leucostigma, $80 \mathrm{~km}$ north of Manaus, Amazonas, Brazil and the rattle call of E) $P$. $l$. leucostigma, El Dorado-La Escalera Road, Bolívar, Venezuela, F) P. s. obscura La Escalera, >1100 m, Bolívar, Venezuela, and G) P. s. saturata, north slope Mt. Roraima, Guyana. Spectrograms were chosen to represent typical values for vocal characters of each form.

to influence mate recognition and the viability of hybrids. The two forms are separated altitudinally and ecologically, but their ranges abut along a relatively long interface $(\sim 260 \mathrm{~km}$ straight line), and there is little or no evidence of intermediacy or hybridization in the available material from nearest the range interface. Thus, it seems clear, based on current knowledge, that saturata should be treated as a species distinct from leucostigma under any applicable species concept (Johnson et al. 1999, Helbig et al. 2002).

Both taxa prefer dense vegetation near water, but saturata is found along clear, swift, montane streams, while leucostigma is often found near swampy pools or slow-flowing streams in level terrain. They are separated altitudinally for the most part, but the separation seems to be more closely tied to ecology than altitude per se, because saturata may be found as low as $125 \mathrm{~m}$ and leucostigma as high $700 \mathrm{~m}$ depending upon locality. Although they have yet to be found syntopically, it seems probable that they do come into contact regularly, because their habitats interdigitate extensively along the entire range interface.

While there is little indication of intermediacy or hybridization at the range interface, we note here the caveat that our closest sampling localities for saturata and leucostigma are $12.5 \mathrm{~km}$ apart. It is not uncommon for narrow hybrid zones to have individual character clines on the order of $10 \mathrm{~km}$ or less in width, yet still involve extensive hybridization and genetic introgres- 
sion (Sattler and Braun 2000, Brumfield et al. 2001). Thus, it would still be of significant interest to document these two forms in syntopy. This might be easiest to do on the Sierra de Lema highway in Venezuela, the only point where their range interface is relatively accessible.

The vocalizations of thamnophilids, like those of other suboscines, are considered to be innate and appropriate "yard sticks" in determining which populations have achieved biological species status (Lanyon 1978, Kroodsma 1984, Isler et al. 1998, Baptista and Kroodsma 2001). The number of vocal characters distinguishing loudsongs of nominate leucostigma and saturata (including obscura) was substantial, equivalent or greater than the number of vocal characters found to differ when vocalizations of syntopic pairs of closely related thamnophilid species were compared in an earlier study (Isler et al. 1998). There is a possibility that differences in calls of leucostigma and saturata will not be diagnostic with larger samples, but we do not consider this an obstacle to species status. Although the calls of closely related sympatric thamnophilid species often differ as much as, or more than their loudsongs, calls of some sympatric species pairs, such as Myrmoborus myotherinus (Black-faced Antbird) and $M$. leucophrys (White-browed Antbird), have not been found to differ diagnosably (Isler et al. 1998). Consequently, on the basis of vocal differences alone, saturata and leucostigma should be considered specifically distinct.

The level of genetic divergence between $s a$ turata and nominate leucostigma is striking. It is almost as high as divergence of either from another recognized species of Percnostola (schistacea), much higher than the already substantial levels of genetic differentiation that have been reported within several other Neotropical suboscine "species" (Bates et al. 1999, Alexio 2002, Marks et al. 2002), and slightly higher than the average sequence divergence between avian congeners reported by Johns and Avise (1998). Although the comparisons of Johns and Avise (1998) are based only on cytochrome $b$, rates of evolution of all the protein-coding mitochondrial genes have been shown to be approximately uniform, with cytochrome $b$ slightly faster than average (Pesole et al. 1999). Therefore, the divergence value derived from our three gene sequences is likely to represent a low estimate of cytochrome $b$ divergence for saturata and leucostigma. Divergence within each taxon was less than $1 \%$; thus, there appears to be a substantial history of genetic isolation between saturata and nominate leucostigma. It is clear that the genetic data strongly support the distinctiveness of these two taxa.

Recognition that saturata is specifically distinct from leucostigma reveals another specieslevel taxon endemic to the Pantepui. This is an important biogeographic pattern that was obscured by a mixture of greater and lesser degrees of geographic variation being treated at the same, subspecific level. Many Neotropical bird species comprise well-marked geographical forms, and our understanding of biogeography and diversification processes is likely to be enhanced by careful analyses of that variation, especially when disparate types of data (morphological, behavioral, genetic) are integrated (Isler et al. 1997, Bierregaard et al. 1997, Krabbe and Schulenberg 1997, Robbins and Stiles 1999).

\section{BIOGEOGRAPHY AND DIVERSIFICATION}

The Pantepui is divided biogeographically into eastern and western subregions by the Río Caroní in southeastern Bolívar, Venezuela (Mayr \& Phelps 1967). P. saturata is known only from the eastern subregion (Willard et al. 1991). Although saturata was reported from Cerro Guaiquinima in the Rio Paragua drainage by Mayr and Phelps (1967), there appears to be no basis for this record (Perez-Eman et al. 2003; PerezEman, pers. comm.). Thus, P. saturata is restricted to the tall tepuis of the eastern subregion, a pattern typical of the most distinctively differentiated tepui endemics, such as Red-banded Fruiteater (Pipreola whitelyi), Rose-collared Piha (Lipaugus streptophorus), and Ruddy Tody-Flycatcher (Poecilotriccus russatum). The high degree of genetic divergence saturata displays from other Percnostola is consistent with this pattern.

The records of saturata reported here include the first definite ones from Guyana (Phelps, 1938, Snyder 1966, Braun et al. 2000) and represent an eastward range extension of $140 \mathrm{~km}$. Because its previously known range was small, this range extension is of significant interest for the conservation of this and other tepui endemics. It represents a substantial increase in the known range of saturata (roughly 67\%), and indicates that a sizeable fraction of the entire pop- 
ulation occurs in Guyana, where there has been little habitat alteration as yet.

Mayr and Phelps (1967) assigned the 96 highland birds of the Pantepui to four classes according to probable origin: a) specialized cliff dwellers (five species), b) altitudinally derived from lowland forms (34 species), c) long-distance colonists from other highland areas (48 species), and d) old endemics (nine species) that may have originated as either b) or c). They naturally classified saturata as altitudinally derived, because they believed it was a subspecies of $P$. leucostigma, which occurs in the adjacent lowlands. We have shown here that saturata is not only distinct from nominate leucostigma, but may not even belong in the leucostigma complex. Thus, its' origin is open to debate. Elevational speciation is still a good possibility, since most species of Percnostola are lowland birds. On the other hand, some Percnostola taxa occur at subtropical elevations in the Andes, suggesting that long-distance colonization is also possible. Another endemic thamnophilid that Mayr and Phelps (1967) classified as altitudinally derived, the Streak-backed Antshrike (Thamnophilus insignis), has now been shown to be the sister taxon of a newly discovered species, Acre Antshrike (Thamnophilus divisorius), from isolated ridges in western Brazil (Whitney et al. 2004), indicating that one of these must have been derived by long-distance colonization from the other.

Altitudinal derivation requires ecological adaptability; long-distance colonization requires dispersal capability. It would be illuminating to understand which actually occurred in this case. A molecular analysis of the leucostigma complex is in progress, which may allow resolution of this issue (Bates et al., unpubl. data). Studies of congeneric species that replace each other on elevational gradients in the Andes suggest a complex interplay of competition, phyletic divergence, and chance in determining species distributions (Terborgh and Weske 1975, Arctander and Fjeldsa 1994, Bates and Zink 1994).

\section{TAXONOMIC RECOMMENDATIONS}

We recommend that saturata be treated as a species in the genus Percnostola sensu Peters (1951) until a thorough revision of that genus is undertaken. We are doubtful of the validity of obscura as subspecifically distinct from satura$t a$, but recognize that more material and a more detailed analysis would be needed to critically determine its diagnosability. It is unclear whether the minor differences in plumage color would prove consistent in larger series or with quantitative spectroscopy of color. No differences were found in their soft part colors, measurements, or vocalizations. The ranges of these highland forms are also unclear as yet. All specimens of saturata (sensu stricto) are from the immediate vicinity of Mt. Roraima, while most obscura localities are $120-210 \mathrm{~km}$ to the northwest. There is one specimen identified as obscura (COP 44636) from Uei-tepuí, which lies about $31 \mathrm{~km}$ to the south-southeast of Mt. Roraima. This implies the curious notion that the range of obscura wraps part way around the range of saturata.

Chubb (1921) used the English name "Roraima Ant-Creeper" for this species. We propose that be modified to Roraiman Antbird to follow current usage for the genus Percnostola. An appropriate Spanish name would be Hormiguero de Roraima.

\section{ACKNOWLEDGMENTS}

We thank B. Barber, K. Bostwick, R. Brumfield, J. Dean, R. Faucett, W. Hinds, C. Milensky, W. Prince, N. Rice, B. O'Shea, B. Schmidt, W. Hinds, and K. Zyskowski for participation in Guyana fieldwork, which was funded by the National Geographic Society and the Smithsonian Biological Diversity of the Guianas Program. G. Barrowclough and P. Sweet (AMNH), D. Causey and A. Pirie (Harvard University), J. Dean (USNM), D. Dittmann (Louisiana State University) and M. Lentino, R. Restall and C. Rodner (COP) facilitated access to specimens. Lentino and Restall also provided critical commentary on COP specimens. DNA lab work was conducted by J. Hunt in the Pritzker Laboratory for Molecular Systematics and Evolution with support from NSF grant \#DEB 9974104 to S. Hackett and JMB. C. Huddleston and T. Hollowell helped produce the final versions of the maps and other figures. We deeply appreciate the continuing support of the Macaulay Library of Natural Sounds of the Cornell Laboratory of Ornithology (G. Budney), and the National Sound Archive, The British Museum (R. Ranftt) in the provision of sound recordings, and we are indebted to the following individuals who contributed vital recordings to the analysis: D. Ascanio, R. Behrstock, R. Bierregaard, M. Cohn-Haft, P. Donahue, D. Finch, P. Gadd, D. Gibbs, T. Gullick, R. Innes, L. Macaulay, C. Milensky, P. Stouffer, B. Whitney, A. Whittaker, D. Willis, and K. Zimmer. A. Aleixo and an anonymous reviewer provided helpful comments on an earlier draft of the manuscript. This is number 93 in the Smithsonian's Biological Diversity of the Guiana Shield Program publication series.

\section{LITERATURE CITED}

Aleixo, A. 2002. Molecular systematics and the role of the "várzea"-"terra firme" ecotone in the di- 
versification of Xiphorhynchus woodcreepers (Aves: Dendrocoplatidae). Auk 119:621-640.

Arctander, P., And J. FJeldsa. 1994. Andean tapaculos of the genus Scytalopus (Aves, Rhinocrytidae): a study of speciation patterns using DNA sequence data, p. 205-225 In V. Loeschcke, J. Tomiuk, and S. K. Jain [EDS.], Conservation genetics. Birkhauser Verlag, Basel, Switzerland.

Baptista, L. F., And D. E. Kroodsma. 2001. Avian bioacoustics, p. 11-52. In J. del Hoyo, A. Elliot, and J. Sargatal [EDS.], Handbook of the birds of the world. Vol. 6. Lynx Edicions, Barcelona, Spain.

Barnett, A., R. Shapley, P. Benjamin, E. Henry, and M. McGarrell. 2002. Birds of the Potaro Plateau, with eight new species for Guyana. Cotinga 18:19-36.

Barrowclough, G. F., P. Escalante-Pliego, R. AveLedo-Hostos, And L. A. PÉrez-Chinchilla. 1995. An annotated list of the birds of the Cerro Tamacuarí region, Serranía de Tapirapecó, Federal Territory of Amazonas, Venezuela. Bulletin of the British Ornithologist's Club 115:211-219.

Barrowclough, G. F., M. Lentino, and P. R. Sweet. 1997. New records of birds from Auyántepuí, Estado Bolívar, Venezuela. Bulletin of the British Ornithologist's Club 117:194-198.

BAtes, J. M., AND R. M. ZinK. 1994. Evolution into the Andes: molecular evidence for species relationships in the genus Leptopogon. Auk 111:507515.

Bates, J. M., S. J. Hackett And J. Goerck. 1999. High levels of mitochondrial DNA differentiation in two lineages of antbirds (Drymophila and Hypocnemis). Auk 116:1093-1106.

BierregaArd, R. O., JR., M. Cohn-HAFt, AND D. Stotz. 1997. Cryptic diversity: an overlooked species and new subspecies of antbird (Aves: Formicariidae) with a revision of Cercomacra tyrannina in northeastern South America. Ornithological Monographs 48:111-128.

Braun, M. J., D. W. Finch, M. B. Robbins, And B. K. SchmidT. 2000. A field checklist of the birds of Guyana. Smithsonian Institution, Washington, DC.

Braun, M. J., M. B. Robbins, C. M. Milensky, B. J. O'Shea, B. R. Barber, W. Hinds, And W. S. PrINCE. 2003. New birds for Guyana from Mts. Roraima and Ayanganna. Bulletin of the British Ornithologist's Club 123:24-33.

Brumfield, R., AND A. P. CAPPARElla. 1996. Historical diversification of birds in northwestern South America: a molecular perspective on the role of vicariant events. Evolution 50:1607-1624.

Brumfield, R. T., R. W. JeRnigan, D. B. McDonald, AND M. J. BRAun. 2001. Evolutionary implications of divergent clines in a manakin (Manacus; Aves) hybrid zone. Evolution 55:2070-2087.

Bush, M. B. 1994. Amazonian speciation: a necessarily complex model. Journal of Biogeography 21 : 5-17.

Capparella, A. P. 1991. Neotropical avian diversity and riverine barriers. Acta Congressus Internationalis Ornithologici 20:307-316.
Chapman, F. M. 1931. The upper zonal bird-life of Mts. Roraima and Duida. Bulletin of the American Museum of Natural History 63:1-135.

Charif, R. A., S. Mitchell, and C. W. Clark. 1995. Canary 1.2 user's manual. Cornell Laboratory of Ornithology, Ithaca, NY.

ChubB, C. 1921. The birds of British Guiana. Vol. 1 (1916), Vol. 2 (1921). Bernard Quaritch, London.

Cook, R. E. 1974. Origin of the highland avifauna of southern Venezuela. Systematic Zoology 23:257264.

Cory, C., AND C. E. Hellmayr. 1924. Catalogue of birds of the Americas. Pteroptochidae-Conopophagidae-Formicariidae. Field Museum of Natural History, Zoological Series 13, Part 3:1-369.

ENDLER, J. A. 1977. Geographic variation, speciation, and clines. Princeton University Press, Princeton, NJ.

ENDLER, J. A. 1982. Pleistocene forest refuges: fact or fancy?, p. 641-657. In G. T. Prance [ED.], Biological diversification in the tropics. Columbia University Press, New York.

HAFFER, J. 1969. Speciation in Amazonian forest birds. Science 165:131-137.

HAFFER J. 1997. Alternative models of vertebrate speciation in Amazonia: an overview. Biodiversity and Conservation 6:451-476.

Helbig, A. J., A. G. Knox, D. T. Parkin, G. SAngster, AND M. Collinson. 2002. Guidelines for assigning species rank. Ibis 144:518-525.

Hilty, S. 2003. Birds of Venezuela. Princeton University Press, Princeton, NJ.

ISLER, M. L. 1997. A sector-based ornithological geographic information system for the Neotropics. Ornithological Monographs 48:345-354.

ISLER, M. L., P. R. IsLer, AND B. M. WhitNey. 1997. Biogeography and systematics of the Thamnophilus punctatus (Thamnophilidae) complex. Ornithological Monographs 48:355-381.

ISLeR, M. L., P. R. IsLeR, AND B. M. Whitney. 1998. Use of vocalizations to establish species limits in antbirds (Passeriformes; Thamnophilidae). Auk 115:577-590.

Isler, M. L., P. R. Isler, AND B. M. Whitney. 1999. Species limits in antbirds (Passeriformes; Thamnophilidae): the Myrmotherula surinamensis complex. Auk 116:83-96.

Isler, M. L., J. Alvarez A., P. R. Isler, And B. M. Whitney. 2001. A new species of Percnostola antbird (Passeriformes: Thamnophilidae) from Amazonian Peru, and an analysis of species limits within Percnostola rufifrons. Wilson Bulletin 113: 164-176.

Johns, G. C., AND J. C. Avise. 1998. A comparative survey of genetic distances in vertebrates from the mitochondrial cytochrome $b$ gene. Molecular $\mathrm{Bi}$ ology and Evolution 15:1481-1490.

Johnson, N. K., J. V. Remsen JR., And C. Cicero. 1999. Resolution of the debate over species concepts in ornithology: a new comprehensive biological species concept. Acta Congressus Internationalis Ornithologici 22:1470-1482.

Krabbe, N., And T. S. Schulenberg. 1997. Species limits and natural history of Scytalopus tapaculos 
(Rhinocryptidae) with descriptions of the Ecuadorian taxa, including three new species. Ornithological Monographs 48:47-88.

Kroodsma, D. E. 1984. Songs of the Alder Flycatcher (Empidonax alnorum) and Willow Flycatcher (Empidonax traillii) are innate. Auk 101:13-24.

LANYON, W. E. 1978. Revision of the Myiarchus flycatchers. Bulletin of the American Museum of Natural History 161:429-627.

Marks, B. B., S. J. Hackett, and A. P. Capparella. 2002. Historical relationships among Neotropical lowland forest areas of endemism as determined by mitochondrial DNA sequence variation within the Wedge-billed Woodcreeper (Aves: Dendrocolaptidae: Glyphorynchus spirurus). Molecular Phylogenetics and Evolution 24:153-167.

Mayr, E., AND W. H. Phelps JR. 1967. The origin of the bird fauna of the south Venezuelan highlands. Bulletin of the American Museum of Natural History 136:273-327.

McDiarmid, R.W., AND M. A. Donnelly. 2005. The Guayana Highlands and its herpetofauna: amphibians and reptiles of the lost world. In M. A. Donnelly, B. I. Crother, C. Guyer, M. H. Wake, and M. E. White [EDS.], Ecology and evolution in the tropics: a herpetological perspective. University of Chicago Press, Chicago. IL.

Meyer de Schauensee, R., And W. H. Phelps JR. 1978. A guide to the birds of Venezuela. Princeton University Press, Princeton, NJ.

Peberdy, P. S. 1941. Ornithological collection from Mount Roraima, p. 30-37. In Reports of the British Guiana Museums and Georgetown Public Free Library, April 26, Georgetown, British Guiana.

Pelzeln, A., von. 1868. Ornithologie Brasiliens, part 2. Vienna, Austria.

Perez-Eman, J., C. J. Sharpe, M. Lentino R., R. O. Prum, AND I. J. Carreno F. 2003. New records of birds from the summit of Cerro Guaiquinima, Estado Bolívar, Venezuela. Bulletin of the British Ornithologist's Club 123:78-90.

Pesole, G., C. Gissi, A. De Chirico, and C. Saccone. 1999. Nucleotide substitution rate of mammalian mitochondrial genomes. Journal of Molecular Evolution 48:427-434.

Peters, J. L. 1951. Check-list of birds of the world Vol. VII. Museum of Comparative Zoology, Cambridge, MA.

PHELPS, W. H., SR. 1938. La procedencia geográfica de las aves coleccionadas en el Cerro Roraima. Boletin de la Sociedad Venezolana de Ciencias Naturales 36:83-95.

Ridgely, R. S., AND G. Tudor. 1994. The birds of South America., Vol. II: the suboscine passerines. University of Texas Press, Austin, TX.

Robbins, M. B., And F. G. Stiles. 1999. A new species of pygmy-owl (Strigidae: Glaucidium) from the Pacific slope of the northern Andes. Auk 116: 305-315.

Roth, V. 1960. Thompson Ayangana expedition. Journal of the British Guiana Museum and Zoo 26:30.

Salvin, O. 1885. A list of the birds obtained by Mr. Henry Whitely in British Guiana. Ibis 1885:418439.
Sattler, G. D., And M. J. Braun. 2000. Morphometric variation as an indicator of genetic interactions between Black-capped and Carolina Chickadees at their contact zone in the Appalachian Mountains. Auk 117:427-444.

SNYDER, D. E. 1966. The birds of Guyana. Peabody Museum, Salem, MA.

Stephens, L., And M. A. Traylor JR. 1985. Ornithological gazeteer of the Guianas. Museum of Comparative Zoology, Cambridge, MA

SteYERMARK, J. A. 1986. Speciation and endemism in the flora of the Venezuelan tepuis, p.317-373. In F. Vuilleumier and M. Monasterio [EDS.], High altitude tropical biogeography. Oxford University Press, Oxford, UK.

Swofford, D. L. 2002. PAUP*: Phylogenetic analysis using parsimony (*and other methods), version 4.0b10. Sinauer Associates, Sutherland, MA.

Terborgh, J. W., And J. S. Weske. 1975. The role of competition in the distribution of Andean birds. Ecology 56:562-576.

ToDD, W. E. C. 1927. New gnateaters and antbirds from tropical America, with a revision of the genus Myrmeciza and its allies. Proceedings of the Biological Society of Washington 40:149-178.

Tuomisto, H., K. Ruokolainen, R. Kalliola, A. LinNA, W. DAnjoy, ANd Z. Rodriguez. 1995. Dissecting Amazonian biodiversity. Science 269:6366.

Wallace, A. R. 1852. On the monkeys of the Amazon. Proceedings of the Zoological Society of London 20:107-110.

Whitney, B. M., D. C. Oren, And R. T. Brumfield. 2004. A new species of Thamnophilus antshrike (Aves: Thamnophilidae) from the Serra do Divisor, Acre, Brazil. Auk 121:1031-1039.

Willard, D. E., M. S. Foster, G. F. Barrowclough, R. W. Dickerman, P. F. Cannell, S. L. Coats, J. L. Cracraft, and J. P. O’NeILl. 1991. The birds of Cerro de la Neblina, Territorio Federal Amazonas, Venezuela. Fieldiana: Zoology, N. S. 65:180.

Zimmer, J. T. 1931. Studies of Peruvian birds. I. New and other birds from Peru, Ecuador, and Brazil. American Museum Novitates 500:1-23.

Zimmer, J. T., And W. H. Phelps SR. 1946. Twentythree new subspecies of birds from Venezuela and Brazil. American Museum Novitates 1312:1-23.

Zimmer, K. J., AND M. L. IsLer. 2003. Family Thamnophilidae (typical antbirds), p. 448-681. In J. del Hoyo, A. Elliot, and D. A. Christie [EDS.], Handbook of the birds of the world,. Vol. 8: broadbills to tapaculos. Lynx Edicions, Barcelona, Spain.

\section{APPENDIX A}

Specimens examined for morphology and genetics. One asterisk $=$ morphology and genetics; two asterisks = genetics only; no asterisks, morphology only. Collection and catalog numbers provided where available. $\mathrm{AMNH}=$ American Museum of Natural History, COP = Colleción Ornitológica Phelps, KUNHM = University of Kansas Natural History Museum, LSUMZ = Louisiana State University Museum of Zoology, MCZ = Museum of Comparative Zoology (Harvard Uni- 
versity), UG = University of Guyana, USNM = US National Museum of Natural History.

P. l. leucostigma- USNM 514988, 514989, 514990, 586393*, 587345**, 609166**, 621445**, 621773*, 625219*, 625220**, 626837*, 626838*, 626941*; UG A295**; KUNHM 86465*, 86466**, 88188*, 88818, $89037 *, 89088^{*}, 89779 * *, 89780 * * ;$ AMNH 125669 , $125670,125671,805716,805717,805718,805719$, 805721, 821532, 821533; MCZ 84556, 84739, 144815, 144816, 144817, 199703; LSUMZ B20357**, B20387**; COP 4 males, 6 females.

P. s. saturata- USNM 626659*, 626773*, 626788*, 626817*, 626876*, 626860*, 626959*; KUNHM 93448*, 93449*, 93450*; AMNH 236689; COP 1 male, 4 females.

P. s. obscura- USNM 383249; AMNH 324720, 324721, COP 27201 (type specimen of obscura, housed at AMNH); MCZ 274825; COP 26 males, 21 females.

\section{APPENDIX B}

The following list identifies recordings used in the study by taxon and locality, with the number of recordings and archive information in parentheses. Acronyms for recording archives: MLNS = Macaulay Library of Natural Sounds, Cornell Laboratory of Ornithology, Ithaca, NY; NSA = National Sound Archive, The British Library, London, UK. ISL = recordings not yet archived in an institutional collection but that have been copied into the inventory maintained by MLI and PRI. Many of these unarchived recordings either are in the process of being archived or will eventually be archived by the recordists.

P. l. leucostigma. (53 recordings) BRAZIL: Amazonas: Manaus, 40-90 km north (10, ISL: AW.017:10, AW.019:10, AW.019:11, AW.019:12; MLNS: 31478, 32504, 48567, 48748, 48593, 74353). GUYANA: Acarai Mtns (2, ISL: MBR.007:02, MBR.007:30); Baramita (3, ISL: MBR.001:15, MBR.001:16, MBR.002: 06); Bartica (2, MLNS: 87541, 87559); Corona Falls (1, MLNS: 98723); Dubulay Ranch (2, ISL: MBR.002: 01, MBR.002:02); Iwokrama Forest Reserve (5, ISL: BMW.144:13, BMW.145:34, MBR.002:03, MBR.002: 04, MBR.002:05); Onoro River, mouth of (2, ISL: MJB.002:08, MJB.002:09); Sipu River (4, ISL: MJB.001:06, MJB.001:07, MJB.001:11, MJB.001:13); Waruma River (5, ISL: MBR.001:13, MBR.001:14, MBR.002:09, MBR.002:12, MBR.002:13,). SURINAME: Brownsberg Nature Reserve (1, ISL: BMW.019:12); Location unknown (1, NSA: 31872); Raleigh Vallen (1, ISL: BMW.020:22). VENEZUELA: Bolívar: El Dorado-La Escalera Road (14, ISL: BMW.015:11, KJZ.005:24, KJZ.005:28, KJZ.005:31, KJZ.114:14, KJZ.114:16, RAB.009:16; MLNS: 60979; NSA: 23903, 26671, 26680, 42843, 68735, 100431)

P. s. saturata. (8 recordings) GUYANA: Kaieteur Fall (2, ISL: MJB.001:39, MJB.001:40); Roraima, north slope Mt. (6, ISL: CM.001:32, CM.001:33, MBR.002:10, MBR.002:11, MJB.002:12, MJB.002: 25).

P. s. obscura. (7 recordings) VENEZUELA: Bolívar: La Escalera $>1100 \mathrm{~m}$ (7, ISL: AW.017:02, AW.017:03, AW.019:13, KJZ.114:15, RAB.006:27; NSA 68311, 68312). 